\title{
MAGEA6 wt Allele
}

National Cancer Institute

\section{Source}

National Cancer Institute. MAGEA6 wt Allele. NCI Thesaurus. Code C104518.

Human MAGEA6 wild-type allele is located in the vicinity of Xq28 and is approximately 4 $\mathrm{kb}$ in length. This allele, which encodes melanoma-associated antigen 6 protein, may enhance ubiquitin ligase activity. 